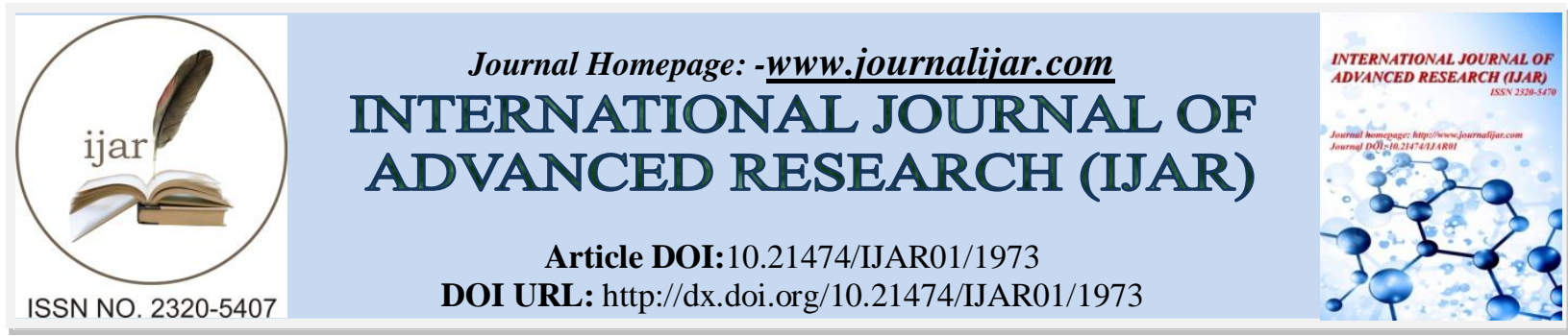

RESEARCH ARTICLE

\title{
DEVELOPMENT AND VALIDATION OF A STABILITY INDICATING ASSAY FOR AZILSARTAN KAMEDOXOMIL IN SOLID DOSAGE FORMS.
}

Mohamed A. Kassem ${ }^{1}$, Magdy I. Mohamed ${ }^{2}$ and Asmaa A. Mohamed ${ }^{3 *}$. Department of Pharmaceutics and Industrial Pharmacy, Faculty of Pharmacy, Cairo University, Cairo, Egypt.

\section{Manuscript Info}

Manuscript History

Received: 12 August 2016

Final Accepted: 22 September 2016

Published: October2016

Key words:-

Azilsartan kamedoxomil, RP-HPLC, validation, Stability indicating assay

\section{Abstract}

A RP-HPLC method was developed and validated for simultaneous determination of kamedoxomil in pharmaceutical preparations such as Edarbi ${ }^{\circledR} 40 \mathrm{mg}$ tablets. In order to develop stability indicating assay method initially the drug was subjected to stress conditions of hydrolysis (acid and base), oxidation, photolysis degradation. Degradation of the drug was observed in acid, alkaline photolysis and peroxide conditions. The Method was validated as per US-FDA guidelines for the estimation of Azilsartan medoxomil using (Kromasil) C18 $(250 \times 4.6 \mathrm{~mm}, 5 \mu)$ column with $0.025 \mathrm{M}$ ammonium acetate (pH 5.0): acetonitrile (30: $70 \%, \mathrm{v} / \mathrm{v})$ as mobile phase, at a flow rate of $2 \mathrm{ml} / \mathrm{min}$. The detection was performed at $254 \mathrm{~nm}$. The calibration curve was found linear in the range of $10-70 \mu \mathrm{g} / \mathrm{ml}$. with correlation coefficient $>0.999$. During calibration experiments. accuracy and precision studies, intra-day and inter-day, \% relative error was found between \pm 15 and \% RSD was less than $15 \%$. The developed method meets the requirements of US-FDA guidelines.

Copy Right, IJAR, 2016,. All rights reserved.

\section{Introduction:-}

Azilsartan kamedoxomil (AZM) is designated chemically as (5-Methyl-2-oxo-1, 3-dioxol-4-yl)methyl 2-ethoxy-1\{[2'-(5-oxo-4,5-dihydro-1,2,4-oxadiazol-3-yl)biphenyl-4-yl]methyl $\}$-1H-benzimidazolecarboxylate monopotassium salt. The active moiety is revealed by hydrolysis of the medoxomil ester. It has molecular formula $\mathrm{C}_{30} \mathrm{H}_{23} \mathrm{KN}_{4} \mathrm{O}_{8}$, molecular weight $606.62^{(1)}$ and it has the following structural formula (Fig.1)

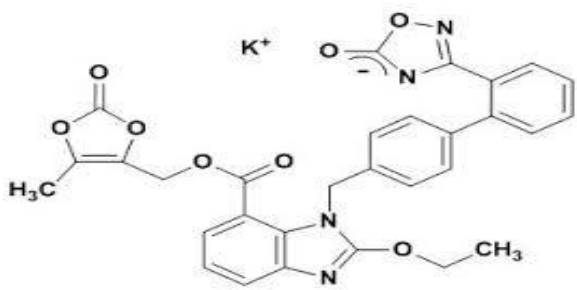

Fig.1:- chemical structure of Azilsartan kamedoxomil

Corresponding Author:- Asmaa A. Mohamed.

Address:- Department of Pharmaceutics and Industrial Pharmacy, Faculty of Pharmacy, Cairo University, Cairo, Egypt. 
Azilsartan medoxomil selectively inhibits angiotensin II from binding to the angiotensin II type-1 receptor (AT1). This receptor inhibition provides the antihypertensive activity of azilsartan medoxomil because it blocks the pressor effects of angiotensin II. Azilsartan medoxomil is a prodrug, it is hydrolyzed to the active moiety, azilsartan, in the gastrointestinal tract during the absorption phase ${ }^{(1)}$ It has a superior ability to control systolic blood pressure relative to other widely used ARBs. Greaterantihypertensive effects of AZL might be due in part to its unusually potent and persistent ability to inhibit bindingof angiotensin II to AT1 receptors ${ }^{(2)}$ Preclinical studies have indicated that azilsartan medoxomil may also benefit cellular mechanisms of cardiometabolic disease and insulinsensitizing activity. ${ }^{(3)}$ Because azilsartan medoxomil is a new product and was recently introduced into the market, it is not yet official in any of the pharmacopeias.

\section{Experimental:-}

\section{Materials:-}

Azilsartan kamedoxomil (AZM) was purchased from Virdev, India, acetonitrile for HPLC; E. Merck, Darmstadt, Germany, hydrochloric acid, ammonium acetate; El-Nasr Pharma. Chem., Cairo, Egypt. Edarbi ${ }^{\circledR} 40 \mathrm{mg}$ tablets was purchased from Takeda, Canada labeled to contain $42.68 \mathrm{mg}$ of azilsartan kamedoxomil (equivalent to $40 \mathrm{mg}$ azilsartan medoxomil). High purity water was prepared by using Waters Milli-Q plus purification system.

\section{Instrumentation:-}

The chromatographic system used to perform development and validation of this method was comprised of an LC10ATvp binary pump, an SPD-M10Avp photo-diode array detector, and autosampler (Shimadzu, Kyoto, Japan (LC Solution, Shimadzu). digital pH meter (Systronics model 802), a sonicator (spectra lab, model UCB 40), The analytical column was a C18 HPLC column, 25 x 4.6 1.D. mm, and particle size $5 \mu \mathrm{m}$ from Kromasil®, USA were used in this study.

\section{Methodology:-}

\section{Chromatographic conditions:-}

Chromatographic analysis was carried out on a C 18 kromasil ${ }^{\circledR}$ column $(250 \times 4.6 \mathrm{~mm}, 5 \mu \mathrm{m})$ The injection volume was $50 \mu \mathrm{l}$ and mobile phase consisting of $0.025 \mathrm{M}$ ammonium acetate (pH: 5.0): acetonitrile (30:70 v/v) at a flow rate of $2 \mathrm{ml} / \mathrm{min}$. The detection was carried out at $254 \mathrm{~nm}$.

\section{Preparation of standard stock solution and working standard solution for azilsartan medoxomil:-}

The stock solution of $(50 \mathrm{mg} / 250 \mathrm{ml})$ of Azilsartan medoxomil was prepared in acetonitrile and was further appropriately diluted with the mobile phase to get seven different working standard solutions with concentration 10 , $20,30,40,50,60$ and $70 \mu \mathrm{g} / \mathrm{ml}$

\section{Sample preparation:-}

10 tablets of Edarbi $40 \mathrm{mg}{ }^{\circledR}$ were weighed and finely powdered. A portion of the powder equivalent to azilsartan medoxomil $(40 \mathrm{mg}$ ) was introduced into a $100 \mathrm{~mL}$ volumetric flask to which $70 \mathrm{~mL}$ acetonitrile: water 50:50 were added and sonicated for $30 \mathrm{~min}$ then made up to volume using the same solvent and filtered through diluted with mobile phase to obtain final concentrations ranging from 10-70 $\mu \mathrm{g} . \mathrm{ml}-1$. The chromatograms of the prepared dilutions were recorded, stored, regression equation was determined; the concentrations of azilsartan kamedoxomil were calculated by substituting values of peak area in the regression equation.

\section{Stress degradation studies:-}

All the reagents used for degradation study (stressors) i.e, $0.1 \mathrm{~N} \mathrm{HCl}, 0.01 \mathrm{~N} \mathrm{NaOH}, 0.1 \mathrm{~N} \mathrm{NaOH}$ and $30 \%(\mathrm{w} / \mathrm{v}$ ) $\mathrm{H} 2 \mathrm{O} 2$ were prepared in 50:50 (v/v) of water and acetonitrile. The drug was subjected to forced degradation until optimum degradation (10-30\%) was achieved. All the degradation studies were conducted at a concentration of 40 $\mathrm{mg}$ of Azilsartan kamedoxomil. The degraded samples were finally diluted to a concentration of $40 \mu \mathrm{g} / \mathrm{mL}$ of Azilsartan kamedoxomil and injected in HPLC system.

\section{Acid degradation:-}

$40 \mathrm{mg}$ of azilsartan kamedoxomil was accurately weighed in a $100 \mathrm{ml}$ volumetric flask containing about $50 \mathrm{ml}$ acetonitrile: water 50:50, $10 \mathrm{ml} 0.1 \mathrm{~N} \mathrm{HCl}$ was added heated on water bath at $70{ }^{\circ} \mathrm{C}$ for $5 \mathrm{~min}$ then transfer and neutralize by base and completed to volume with the mobile phase. $10 \mathrm{ml}$ was diluted to $100 \mathrm{ml}$ with mobile phase. 


\section{Base degradation:-}

- $40 \mathrm{mg}$ of azilsartan kamedoxomil powder was accurately weighed in a $100 \mathrm{ml}$ volumetric flask containing about $50 \mathrm{ml}$ acetonitrile: water $50: 50,10 \mathrm{ml} 0.01 \mathrm{~N} \mathrm{NaOH}$ was added heated on water bath at temperature of $70{ }^{\circ} \mathrm{C}$ for 5 min then transfer and was neutralized by acid and completed to volume with the mobile phase. $10 \mathrm{ml}$ was diluted to $100 \mathrm{ml}$ with mobile phase.

- $40 \mathrm{mg}$ of azilsartan kamedoxomil powder was accurately weighed in a $100 \mathrm{ml}$ volumetric flask containing about $50 \mathrm{ml}$ acetonitrile: water $50: 50,10 \mathrm{ml} 0.1 \mathrm{~N} \mathrm{NaOH}$ was added heated on water bath at temperature of $70{ }^{\circ} \mathrm{C}$ for 5 min then transfer and was neutralized by acid and completed to volume with the mobile phase. $10 \mathrm{ml}$ was diluted to $100 \mathrm{ml}$ with mobile phase.

\section{Peroxide degradation:-}

- $40 \mathrm{mg}$ of azilsartan kamedoxomil powder was accurately weighed in a $100 \mathrm{ml}$ volumetric flask containing about $50 \mathrm{ml}$ acetonitrile: water 50:50, $5 \mathrm{ml}$ of $30 \%(\mathrm{w} / \mathrm{v}) \mathrm{H} 2 \mathrm{O} 2$ was added heated on water bath at temperature of $70{ }^{\circ} \mathrm{C}$ for $2 \mathrm{~min}$ then transfer and completed to volume with the mobile phase. $10 \mathrm{ml}$ was diluted to $100 \mathrm{ml}$ with mobile phase.

\section{Photolytic degradation:-}

Azilsartan kamedoxmil solution of $100 \mu \mathrm{g} / \mathrm{ml}$ to UV Light by keeping the beaker in UV Chamber for 7days or 200 Watt hours $/ \mathrm{m} 2$ in photo stability chamber. For HPLC study, the resultant solution was diluted to obtain $40 \mu \mathrm{g} / \mathrm{ml}$ and $50 \mu 1$ were injected into the system and the chromatograms were recorded to assess the stability of sample ${ }^{(4,5)}$

\section{Method validation:-}

The developed method was validated to establish the specificity, precision, linearity, accuracy and robustness according to ICH guidelines, USP ${ }^{(6-7)}$.

\section{Linearity:-}

The peak area chromatogram of azilsartan kamedoxomil in the range of $\left(10-70 \mu \mathrm{g} \cdot \mathrm{ml}^{-1}\right)$, The calibration curve at 254 $\mathrm{nm}$ to the drug concentrations was constructed the regression equation was calculated for different concentrations of azilsartan kamedoxomil standard solution using acetonitrile: water 50:50 and diluted obtain final dilution corresponding to the following concentrations: $10,20,30,40,50,60$ and $70 \mu \mathrm{g} \cdot \mathrm{ml}^{-1}$ using the mobile phase, the regression equation, the correlation coefficient, slope of the regression line, and residual standard deviation (SD) were calculated

\section{Specificity:-}

The terms specificity and selectivity are often used interchangeably as both the USPand the ICH ${ }^{(6)}$ currently use the term specificity, it will also be used here to avoid any confusion. The USP ${ }^{(7)}$ defines specificity as the ability to measure accurately and specifically the analyte of interest in the presence of other components in the sample matrix. These components may include other active ingredients, excipients, impurities, and degradation products. According to the $\mathrm{ICH},{ }^{(6)}$ the validation procedure should be able to demonstrate the ability of the method to assess unequivocally the analyte in the presence of impurities, matrix components, and degradation products. It was done by preparing placebo \{all contents of tablets without adding active ingredient $\}$ was injected, and peak area should not appear at the retention time specified for azilsartan kamedoxomil.

\section{Accuracy}

Accuracy is the measure of how close the experimental value is to the true value. It should be established across the specified range (that is, line of working range) of the analytical procedure.

Assay percentage to the labeled claim: The analytical method procedure was performed by preparing triplicates of 3 different test solution concentrations $80 \%, 100 \%, 120 \%$ as FDA ${ }^{(8)}$ recommended (in this assay were $32,40,48 \mu \mathrm{g} . \mathrm{ml}$ $\left.{ }^{-1}\right)$, and $\%$ Azilsartan kamedoxomil was calculated .The data should be calculated as percent of label claim, and the mean of the replicates along with \% Relative Standard Deviation (RSD) for each level reported to demonstrate accuracy and sample analysis precision.

Percentage recovery: Determination of the percentage recovery of added known amount of pure azilsartan kamedoxomil reference standard to the test solution sample to prove the accuracy of the analytical method. After the addition of $\left(10,15,20,25,30 \mu \mathrm{g} \cdot \mathrm{ml}^{-1}\right)$, the final tests concentrations were respectively $\left(50,55,60,65,70 \mu \mathrm{g} \cdot \mathrm{ml}^{-1}\right)$, 
Triplicates of these test concentrations were prepared and assayed and \% recovered were computed. The data should be calculated as percent of label claim, and the mean of the replicates along with \% RSD for each level reported to demonstrate accuracy and sample analysis precision.

\section{Precision:-}

Precision is the measure of how close the data values are to each other for a number of measurements under the same analytical conditions or "the degree of agreement among individual tests results obtained by repeatedly applying the analytical method to multiple samplings of homogenous sample"

\section{Repeatability:-}

6 test solutions having all $100 \%$ of test or target concentrations were prepared following the test preparation procedure in the analytical method and having all the same concentrations of $\left(40 \mu \mathrm{g} \cdot \mathrm{ml}^{-1}\right)$. Results obtained stored and computed. RSD should be not more than \pm 1 as FDA recommended.

\section{Ruggedness (Intermediate precision):-}

Intermediate precision expresses within-laboratory variations. This was previously evaluated as part of ruggedness. This attribute evaluates the reliability of the method. The data obtained from the interday and intraday confirm the ruggedness of the used analytical method.

\section{Interday:-}

The previous procedure was repeated three times on three different days for the analysis of the concentrations, The concentrations were calculated from the corresponding regression equation.

\section{Intraday:-}

The previous procedure was repeated three times on different time intervals on the same day for the analysis of the concentrations, the concentrations were calculated from the corresponding regression equation.

\section{Robustness:-}

The robustness of an analytical procedure is a measure of its capacity to remain unaffected by small but deliberate variations in some parameters and provide an assurance of its reliability during normal usage. The robustness of the method is investigated by varying some or all conditions, e.g., organic composition of the mobile phase, $\mathrm{pH}$, ionic strength, column temperature, age of column, column type. ICH ${ }^{(6)}$ guidelines recommend that robustness studies be performed during the method development stage. Robustness can also be partly assured by good system suitability specification. Therefore, it is important to set tight but realistic system suitability specifications. the method was assured that it is robust by making slight change Robustness of the method was investigated by varying the instrumental conditions such as flow rate $( \pm 10 \%)$, column oven temperature $( \pm 5 \%)$, wave length of detection $( \pm 5 \mathrm{~nm})$, organic content in mobile phase $( \pm 2 \%)$ and $\mathrm{pH}$ of buffer in mobile phase ( \pm 0.2 units).

\section{Lower Limit of Detection (LLOD):-}

Lower limit of detection (LLOD) is the lowest concentration of the analyte that can be detected, but not necessarily quantitated, under the stated experimental conditions. It is a parameter of limit test and specifies whether or not an analyte is above or below a certain value. Determination of limit of detection is described for instrumental and noninstrumental methods. For instrumental methods, one determines the signal-to-noise ratio by comparing test results from samples with known concentration of analyte with those of blank samples and establishes the lowest concentration at which analyte can be reliably detected. A signal-to-noise ratio of 2:1 or 3:1 is required. Another approach is to calculate the standard deviation for analysis of a number of blank samples. The standard deviation multiplied by a factor, usually 2 or 3 , gives an estimate of limit of detection.

The detection limit may be calculated based on the standard deviation of the residuals (SD) and slope (S) of the calibration curve (a specific curve should be generated by using samples containing analyte in the range of detection limit), according to the formula:

$\mathrm{LLOD}=3.3 \mathrm{X} \mathrm{SD} / \mathrm{S}$

Where SD is standard deviation of residuals, $\mathrm{S}$ is slope of line of calibration curve 


\section{Lower Limit of Quantitation (LLOQ):-}

Lower limit of quantitation (LLOQ) is the lowest concentration of the analyte that can be determined with Acceptable precision and accuracy under the stated experimental conditions of method, this I a parameter of the quantitative assay for low concentrations of compounds in sample matrices such s degradation product in the finished product. USP LLOQ is similar to LLOD, is expressed as conc. of the analyte in the sample, and precision and accuracy are also reported. LLOQ is dependent on the type of procedure, i.e., instrumental or noninstrumental. For instrumental, sometimes signal to noise ratio of 10:1 is used to determine LLOQ. ICH lists the same two options that can be us to determine LLOQ. The evaluation for instrumental or noninstrumental; the latter method based on standard deviation of the response and the slope.

\section{LLOQ $=10 \mathrm{X}$ SD $/ \mathrm{S}$}

Where SD is standard deviation of residuals, $\mathrm{S}$ is slope of line of calibration curve

\section{System Suitability:-}

The system suitability specifications are parameters that provide assistance in achieving this purpose. According to the $\mathrm{ICH}^{(6)}$ and the USP ${ }^{(7)}$. System suitability tests are performed prior to analysis of actual samples. These parameters are studied by analysis of a system suitability sample that is a mixture of main active drug and expected by-product or a known impurity. Parameters required such as tailing factor $(T)$ should be for azilsartan kamedoxomil not be more than 2 , Resolution $\left(R_{\mathrm{S}}\right)$ should be more than 2 if there is more than one peak ], capacity factor $\left(k^{\prime}\right)$ should be more than 2 and plate count should be not less than $2000^{(8-10)}$

\section{Stability of solutions:-}

Many solutes readily decompose prior to chromatographic investigations, for example, during the preparation of the sample solutions, extraction, cleanup, phase transfer or storage of prepared vials (in refrigerators or in an automatic sampler). Under these circumstances, method development should investigate the stability of the analytes and standards.

The term system stability has been defined as the stability of the samples being analyzed in a sample solution. It is a measure of the bias in assay results generated during a preselected time interval, for example, every hour up to 46 hours, using a single solution. System stability should be determined by replicate analysis of the sample solution. System stability is considered appropriate when the RSD, calculated on the assay results obtained at different time intervals, does not exceed more than 20 percent of the corresponding value of the system precision. If, on plotting the assay results as a function of time, the value is higher, the maximum duration of the usability of the sample solution can be calculated.

Stability of standard solution checked by analyzing solutions prepared according to the standard preparation described in test method, each containing (the concentration of standard) at different time interval for $48 \mathrm{hr}$ at room temperature and comparing to freshly prepared standard solution. Stability of test solution checked by analyzing solutions prepared according to the test preparation described in test method, each containing (the concentration of test) at different time interval for $48 \mathrm{hr}$ at room temperature and comparing to freshly prepared standard solution
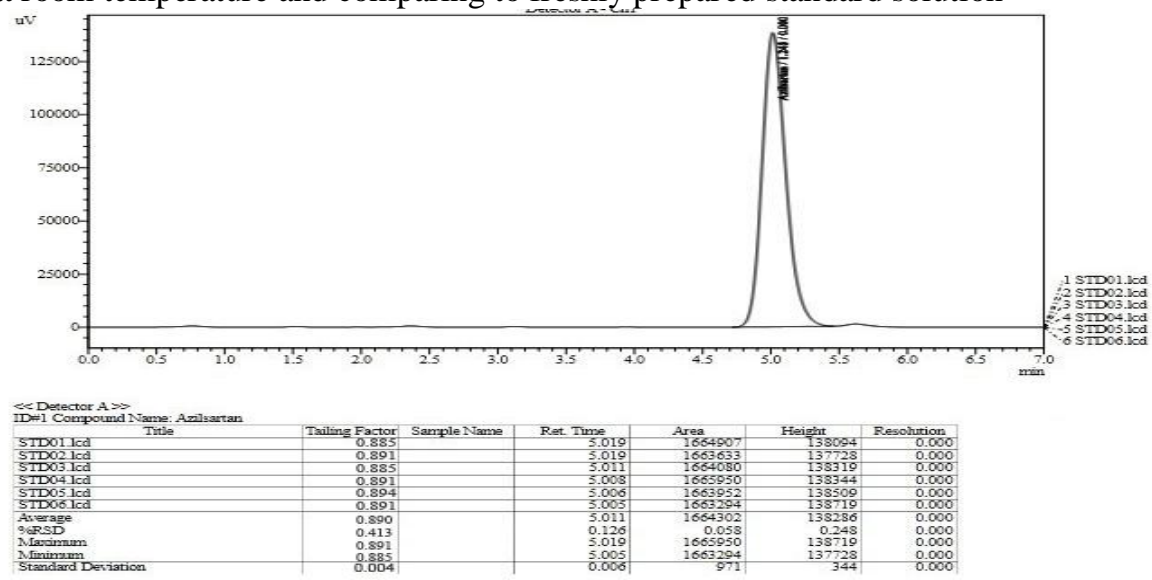

Fig. 2:- Typical LC chromatogram for $40 \mu \mathrm{g}$. $\mathrm{mL}^{-1}$ azilsartan kamedoxmil standard ( $5 \mathrm{~min}$ ) and under the descriedchromatographic conditions 


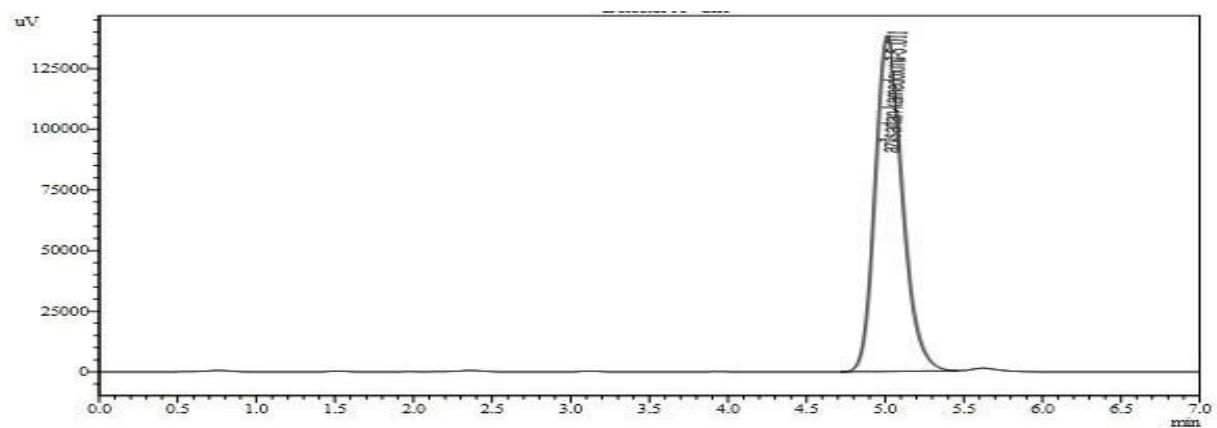

Fig 3:- Typical LC chromatogram for Edarbi 40mg ® tablets-eq. to $40 \mu \mathrm{g} / \mathrm{mL}$ Azilsartan medoxomil ( $5.011 \mathrm{~min}$ ) and under the descried chromatographic conditions.

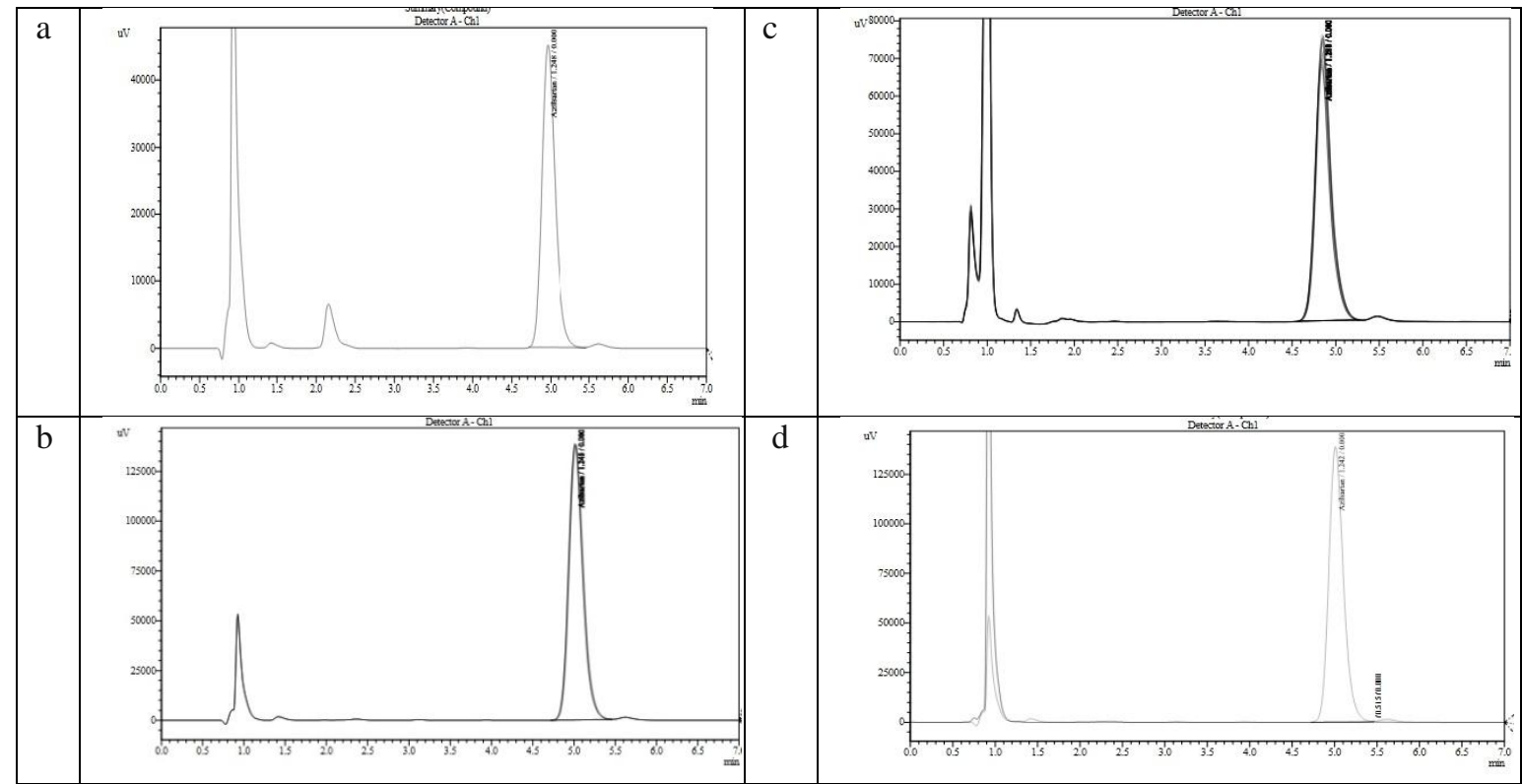

Fig. 4:- LC chromatograms of $40 \mu \mathrm{g} \cdot \mathrm{mL}^{-1}$ azilsartan kamedoxomil under different stress degradation conditions-a) acidic $(0.1 \mathrm{~N} \mathrm{HCl})$, b alkaline $(0.01 \mathrm{~N} \mathrm{NaOH})$, c. photolytic, d. oxidative $(30 \% \mathrm{H} 2 \mathrm{O} 2$, w/v) at $254 \mathrm{~nm}$ using the described degradation and chromatographic conditions.

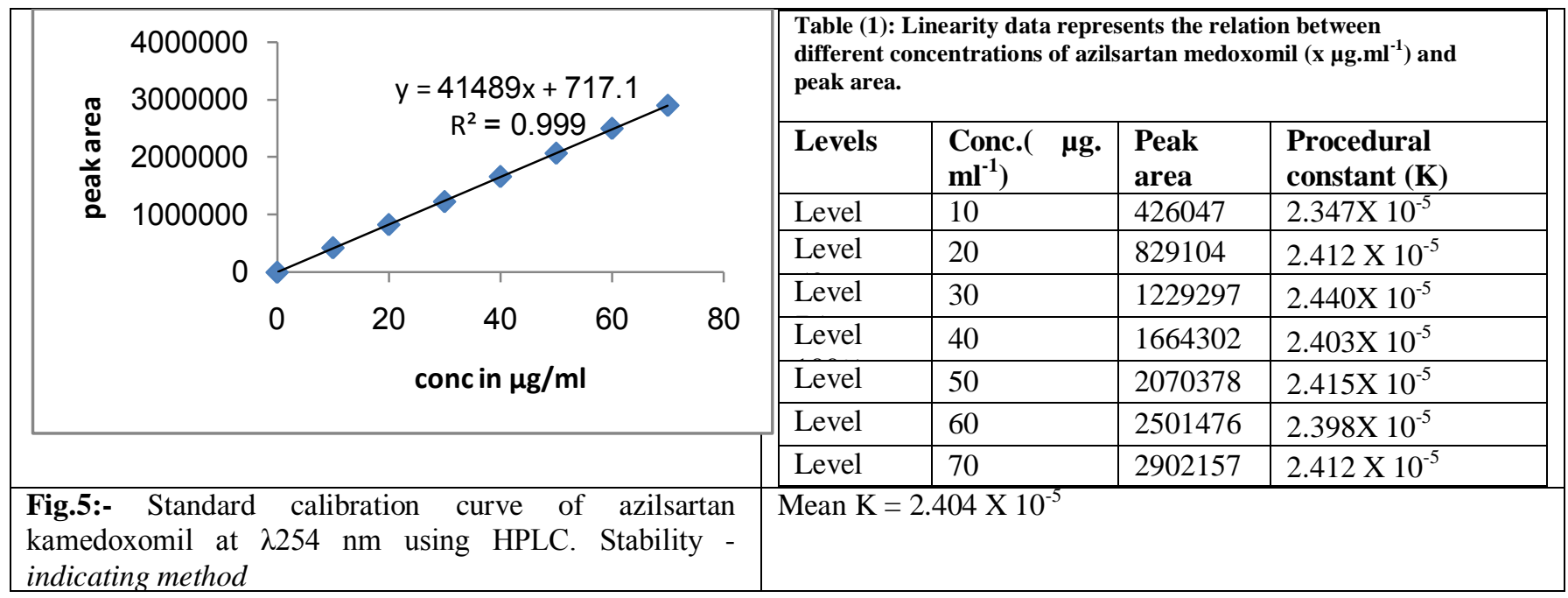




\begin{tabular}{|c|c|c|c|}
\hline \multicolumn{4}{|c|}{ Table.2 :accuracy } \\
\hline \multicolumn{4}{|c|}{ Table (2.a): Assay percentage } \\
\hline \begin{tabular}{|l} 
Sample \\
size
\end{tabular} & $\begin{array}{l}\text { Peak area } \\
(\text { mean } \pm \text { SD })\end{array}$ & $\begin{array}{l}\text { Mean } \\
\% \pm \text { SD }\end{array}$ & $\begin{array}{l}\text { Obtained Result } \\
\times 100 \\
\text { Theoretical result }\end{array}$ \\
\hline $\begin{array}{l}30 \mu \mathrm{g} / \mathrm{ml}( \\
75 \% \text { of } \\
\text { the } \\
\text { labeled } \\
\text { amount) }\end{array}$ & $1225308 \pm 6977$ & $\begin{array}{l}74.056 \% \\
\pm 0.2\end{array}$ & $98.742 \%$ \\
\hline $\begin{array}{l}40 \\
\mu \mathrm{g} / \mathrm{ml}(10 \\
0.0 \% \text { of } \\
\text { the } \\
\text { labeled } \\
\text { amount). }\end{array}$ & $1654187 \pm 12091$ & $\begin{array}{l}100.273 \\
\% \pm 0.52\end{array}$ & $100.273 \%$ \\
\hline $\begin{array}{l}50 \mu \mathrm{g} / \mathrm{ml} \\
(125.0 \% \\
\text { of the } \\
\text { labeled } \\
\text { amount })\end{array}$ & $2066672 \pm 7244$ & $\begin{array}{l}124.709 \\
\% \pm 0.097\end{array}$ & $99.767 \%$ \\
\hline & & & $\mathrm{X}^{-}=99.594 \% \pm 0.78$ \\
\hline
\end{tabular}

$\mathrm{n}=3$ (three determination).

\section{Table (2.b): Percentage recovery}

\begin{tabular}{|c|c|c|c|c|}
\hline $\begin{array}{l}\text { Added } \\
\text { amountof } \\
\text { azilsartan } \\
\text { kamedoxomil } \\
\end{array}$ & $\begin{array}{l}\text { Peak area } \\
(\text { mean } \pm \text { SD })\end{array}$ & $\begin{array}{l}\text { Mean\% } \pm \\
\text { SD }\end{array}$ & $\begin{array}{l}\% \\
\text { Recover } \\
\text {-ed }\end{array}$ & \% Recovery \\
\hline $\begin{array}{l}8 \\
\mu \mathrm{g} / \mathrm{ml} .(=20 \\
\% \text { of labeled } \\
\text { amount) }\end{array}$ & $\begin{array}{l}1984369 \pm \\
11177.9\end{array}$ & $\begin{array}{l}119.26 \% \pm \\
0.548\end{array}$ & $19.67 \%$ & $98.33 \%$ \\
\hline $\begin{array}{l}12 \mu \mathrm{g} / \mathrm{ml} . \\
(=30 \% \\
\text { labeled } \\
\text { amount })\end{array}$ & $\begin{array}{l}2160515 \pm \\
2875.9\end{array}$ & $\begin{array}{l}129.85 \% \pm \\
0.17\end{array}$ & $30.25 \%$ & $100.84 \%$ \\
\hline $\begin{array}{l}16 \mu \mathrm{g} / \mathrm{ml} . \\
(=40 \% \text { of } \\
\text { labeled } \\
\text { amount })\end{array}$ & $\begin{array}{l}2323208 \pm \\
9950.7\end{array}$ & $\begin{array}{l}139.62 \% \pm \\
0.6\end{array}$ & $40.03 \%$ & $100.08 \%$ \\
\hline $\begin{array}{l}20 \mu \mathrm{g} / \mathrm{ml} \\
(=50 \% \text { of } \\
\text { labeled } \\
\text { amount })\end{array}$ & $\begin{array}{l}2496136 \pm \\
5908.4\end{array}$ & $\begin{array}{l}150.02 \% \pm \\
0.35\end{array}$ & $50.42 \%$ & $100.85 \%$ \\
\hline $\begin{array}{l}24 \mu \mathrm{g} / \mathrm{ml} . \\
(=60 \% \text { of } \\
\text { labeled } \\
\text { amount })\end{array}$ & $\begin{array}{l}2663688 \pm \\
3972.6\end{array}$ & $\begin{array}{l}160.09 \% \pm \\
0.24\end{array}$ & $60.49 \%$ & $100.8 \%$ \\
\hline \multicolumn{5}{|c|}{$\begin{array}{l}\text { Mean } \% \text { recovery } \pm S D=100.18 \% \pm 1.084 \\
\text { Error }=0.18\end{array}$} \\
\hline
\end{tabular}

\section{Table .3 : precision}

Table (3.a): Repeatability

\begin{tabular}{|c|c|c|c|}
\hline $\begin{array}{l}\text { Test } \\
\text { no }\end{array}$ & $\begin{array}{l}\text { Con } \\
\text { c. }\end{array}$ & Peak area & \% Result \\
\hline $\mathrm{T} 1$ & \multirow{6}{*}{$\begin{array}{l}100 \\
\%\end{array}$} & 1662219 & 100.117 \\
\hline $\mathrm{T} 2$ & & 1659270 & 99.939 \\
\hline T3 & & 1664375 & 100.247 \\
\hline $\mathrm{T} 4$ & & 1665071 & 100.247 \\
\hline T5 & & 1662941 & 100.160 \\
\hline T6 & & 1646641 & 99.179 \\
\hline & & & $\begin{array}{l}\text { Mean } \% \pm \text { SD } \\
=99.981 \% \pm 0.41 \\
\text { RSD }=0.41 \%\end{array}$ \\
\hline
\end{tabular}

Table (3.b): Intraday- Ruggedness

\begin{tabular}{|l|l|l|}
\hline S No. & Analyst I & Analyst II \\
\hline $\mathbf{1}$ & $100.24 \%$ & $99.53 \%$ \\
\hline $\mathbf{2}$ & $99.85 \%$ & $100.23 \%$ \\
\hline $\mathbf{3}$ & $99.65 \%$ & $99.85 \%$ \\
\hline $\mathbf{4}$ & 100.21 & $99.75 \%$ \\
\hline $\mathbf{5}$ & & \\
\hline $\mathbf{6}$ & $100.13 \%$ & $100.22 \%$ \\
\hline Mean & $100.06 \%$ & $99.49 \%$ \\
\hline SD & $100.06 \%$ & $99.49 \%$ \\
\hline RSD & $100.02 \%$ & $99.85 \%$ \\
\hline Overall mean & 0.23 & 0.32 \\
\hline Overall SD & $99.94 \%$ & $0.32 \%$ \\
\hline Overall RSD & 0.12 & \\
\hline & $0.12 \%$ & \\
\hline
\end{tabular}




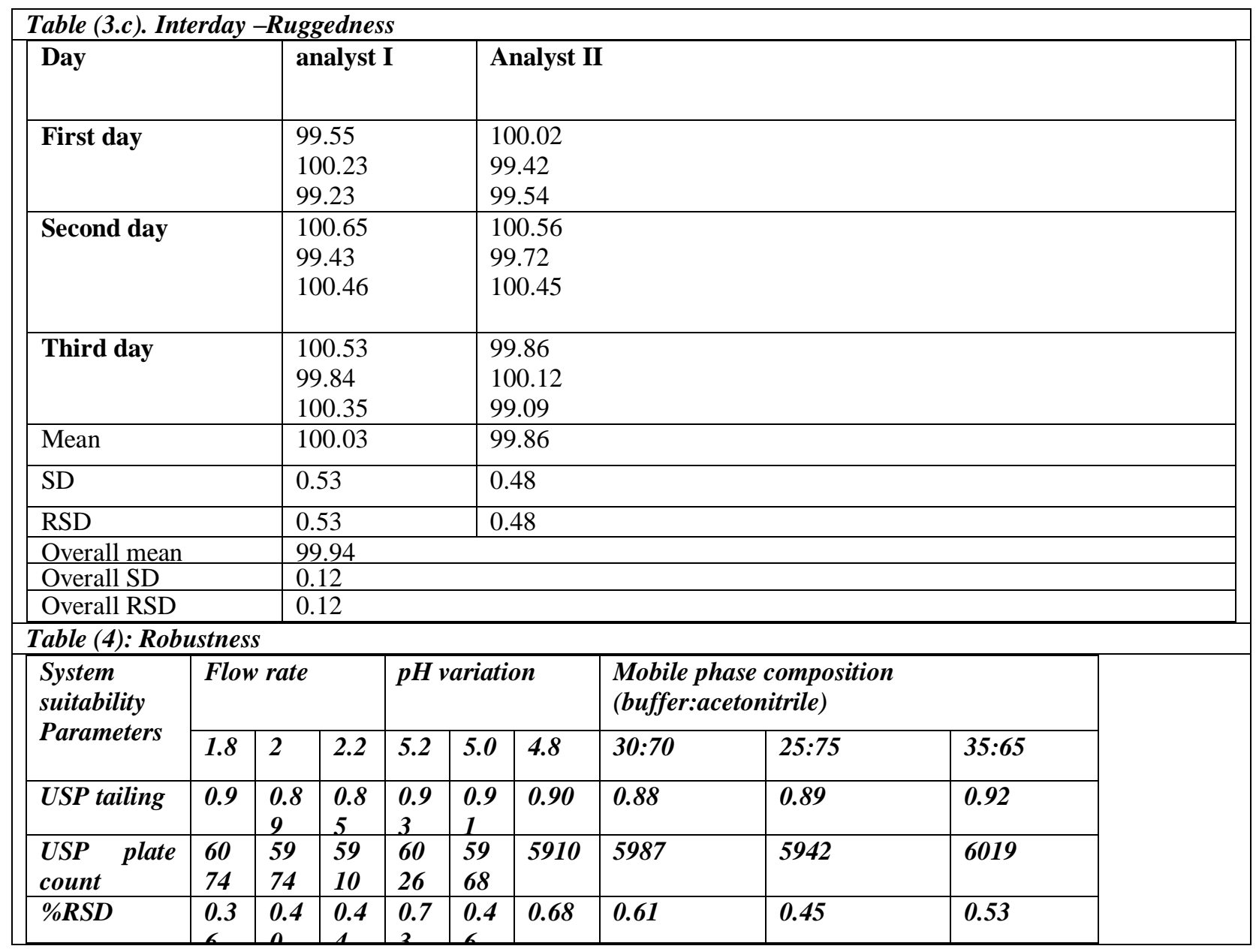

\begin{tabular}{|c|c|c|c|c|c|c|c|c|c|}
\hline \multicolumn{10}{|c|}{ Table (5) } \\
\hline \multicolumn{5}{|c|}{ Table (5.a): Stability of standard solution. } & \multicolumn{5}{|c|}{ Table (5.a): Stability of test solution. } \\
\hline Day & $\begin{array}{l}\text { Fresh } \\
\text { standard } \\
\text { (Mean peak } \\
\text { area) }\end{array}$ & $\begin{array}{l}\text { Test at } \\
\text { room } \\
\text { temperature } \\
\text { (Mean peak }\end{array}$ & $\begin{array}{l}\text { Mean } \% \\
\pm S D\end{array}$ & $\begin{array}{l}\% \\
R S D\end{array}$ & Day & $\begin{array}{l}\text { Fresh } \\
\text { standard } \\
\text { (Mean }\end{array}$ & $\begin{array}{l}\text { Test at } \\
\text { room } \\
\text { temperat }\end{array}$ & $\begin{array}{l}\text { Mean } \\
\% \pm S D\end{array}$ & $\begin{array}{l}\% \\
R S D\end{array}$ \\
\hline $\begin{array}{l}\text { First } \\
\text { day }\end{array}$ & $\begin{array}{l}165275 \\
5 \pm 3810\end{array}$ & $\begin{array}{l}1652310 \pm \\
3361\end{array}$ & $\begin{array}{l}99.97 \pm \\
0.035\end{array}$ & 0.035 & First day & $\begin{array}{l}1651422 \\
\pm 2814\end{array}$ & $\begin{array}{l}1652182 \pm \\
2709\end{array}$ & $\begin{array}{l}100.03 \pm \\
0.025\end{array}$ & 0.025 \\
\hline \multirow[t]{2}{*}{\begin{tabular}{|l|} 
Seco- \\
nd \\
day
\end{tabular}} & $\begin{array}{l}1650482 \pm \\
1452\end{array}$ & $\begin{array}{l}1650572 \pm \\
1126\end{array}$ & $\begin{array}{l}100.01 \pm \\
0.031\end{array}$ & 0.031 & $\begin{array}{l}\text { Second } \\
\text { day }\end{array}$ & $\begin{array}{l}1652081 \pm \\
3226\end{array}$ & $\begin{array}{l}1651349 \pm \\
3308\end{array}$ & $\begin{array}{l}99.95 \pm \\
0.026\end{array}$ & 0.026 \\
\hline & & & & $\begin{array}{l}\text { Mean } \\
\text { RSD= }= \\
\mathbf{0 . 0 3 3}\end{array}$ & & & & & $\begin{array}{l}\text { Mean } \\
\text { RSD= } \\
\mathbf{0 . 0 2 5} \\
\end{array}$ \\
\hline \multicolumn{5}{|c|}{$\mathrm{n}=3$ (three determination). } & \multicolumn{5}{|c|}{$\mathrm{n}=3$ (three determination). } \\
\hline
\end{tabular}


Table 6:- data of forced degradation.

\begin{tabular}{|l|l|l|}
\hline Sample condition & \% assay & \% difference \\
\hline Untreated sample & 100.12 & ------- \\
\hline Acid treated & 79.23 & 20.89 \\
\hline Alkali treated & 32.76 & 67.36 \\
\hline Peroxide treated & 94.38 & 5.74 \\
\hline Photolytic degradation & 89.58 & 10.54 \\
\hline
\end{tabular}

Table 7:-Results of validation obtained by applying the developed HPLC method for determination of azilsartan kamedoxomil

\begin{tabular}{|l|l|}
\hline Parameters & Results \\
\hline Range $(\mu \mathrm{g} / \mathrm{ml})$ & $10-70$ \\
\hline LLOD $(\mu \mathrm{g} / \mathrm{ml})$ & 0.832 \\
\hline LLOQ $(\mu \mathrm{g} / \mathrm{ml})$ & 2.521 \\
\hline Slope & 41489 \\
\hline Intercept y & 717.17 \\
\hline Mean \pm SD & $99.981 \% \pm 0.41$ \\
\hline Correlation coefficient $\mathrm{r}^{2}$ & 0.9999 \\
\hline Percentage relative error & 0.18 \\
\hline RSD $\%$ intraday & 0.12 \\
\hline RSD $\%$ interday & 0.12 \\
\hline Tailing factor & 0.890 \\
\hline Capacity factor & 5.940 \\
\hline Plate count & 59 \\
\hline
\end{tabular}

\section{Results and Discussion:-}

When Azilsartan medoxomil were subjected to chromatographic analysis in mobile phases of different strengths and compositions, it was found that mobile phase consisting of $0.025 \mathrm{M}$ ammonium acetate (pH: 5.0 ): acetonitrile (30:70 $\mathrm{v} / \mathrm{v}$ ) gave adequate retention at a flow rate of $2 \mathrm{ml} / \mathrm{min}$. The wavelength at which detection was carried out was 254 $\mathrm{nm}$. The retention time for Azilsartan medoxomil was $5.011 \mathrm{~min}$. A linear calibration curve was obtained in the concentration range $\left(10-70 \mu \mathrm{g} \cdot \mathrm{ml}^{-1}\right)$ representing the relationship between concentration and the response (peak area) as shown in Fig. (2) and table (1).

$\mathrm{Y}=41489 \mathrm{X}+717.17$

$$
r^{2}=0.9999
$$

Where $\mathrm{Y}$ is the peak area at $254 \mathrm{~nm}, \mathrm{X}$ is the concentration in $\mu \mathrm{g} \cdot \mathrm{ml}^{-1}$ and $\mathrm{r}^{2}$ is correlation coefficient.

The validity of the developed method was further assessed by applying the standard addition technique for the analysis of Edarbi $40 \mathrm{mg}$ tablets. The method found to be linear over range 10-70 $\mu \mathrm{g} \cdot \mathrm{ml}^{-1}$, the correlation coefficient ( $\mathrm{r}^{2}$ ), standard deviation (SD) and slope were found to be $0.9999,717.17$ and 41489, respectively (table 1and Fig.10). Mean accuracy was $99.594 \% \pm 0.78$; with mean percent recovery was found to be $100.18 \% \pm 1.084$ as shown in tables $(2$.a, 2.b). The method was shown to be selective and specific. The method was shown to be precise since repeatability mean percent resulted was $99.981 \% \pm 0.41, \mathrm{RSD}=0.41 \%$, table (3). The method also was found to be rugged and RSD did not exceed $0.5 \%$ as shown in tables $(4 . a, 4 . b)$.

The method was found robust as slight changes $( \pm 0.2)$ in flow from $2 \mathrm{ml} / \mathrm{min}$ to $2.2 \mathrm{ml} / \mathrm{min}, 1.8 \mathrm{ml} / \mathrm{min}$ and the $\mathrm{pH}$ of buffer of mobile phase changed $( \pm 0.2)$ from 5.5 to 5.3 and 5.7 did not affect the results significantly as RSD was less than $1 \%$. Results are shown in table (5). Lower limit of detection (LLOD) was found to be $0.832 \mu \mathrm{g} / \mathrm{ml}$ and Lower limit of quantitation (LLOQ) was found to be $2.521 \mu \mathrm{g} / \mathrm{ml}$. System was suitable as tailing was 0.89 [Tailing should be not more than 2], plate count was found to be more than 5967 and capacity factor was found to be 5.940 [limit not less than 2]

The solutions of both standard and test were found to be stable as the RSD of stability were found to be $0.033 \%$ and $0.025 \%$, respectively where the values were found to be less than $20 \%$ percent of RSD precision of the method. 
The Data for Forced degradation are tabulated in Table (6). There was no interference of any peak at the retention time of analyte peaks from blank and placebo

\section{Conclusion:-}

In this report, a simple, rapid, selective and accurate HPLC-UV method was described for the quantification of Azilsartan medoxomil in solid dosage form in the concentration range of $10-70 \mu \mathrm{g} / \mathrm{ml}$. The method meets the requirements of the US-FDA guidelines.

\section{References:-}

1. Jones, D. J., Jackson, H.S. , Agboton, C. and Martin, S.T.; Azilsartan Medoxomil (Edarbi) The eighth angiotensin II receptor blocker, Pubpubmed Med Central ${ }^{\circledR}$ journal); 36(10): 634-636, 638-640. (2011)

2. Kurtz, T.W. and Kajiya, T.; Differential pharmacology and benefit/ risk of azilsartan compared to other sartans, Vasc Health Risk Manag; 8:133-143(2012)

3. Kusumoto, K., Igata, H., Ojima, M., Tsuboi, A., Imanishi, M., Yamaguchi, F., Sakamoto, H., Kuroita, T., Kawaguchi, N., Nishigaki, N., Nagaya, H.; Antihypertensive, insulin-sensitising and renoprotective effects of a novel, potent and long-acting angiotensin II type 1 receptor blocker, azilsartan medoxomil, in rat and dog models, Eur J Pharmacol; 669:84-93(2011)

4. Bhavyasri, K., Balaram,M.V., Nageswarao, Rambabu, D., Goud,S.E. and Ajitha1, M.; Development and validation of forced degradation studies of raltegravir using RP-HPLC and characterization of degradants by LC-MS/MS, J. Pharm. Sci. \& Res.; 7(9), 685-689 685(2015)

5. Gandhi, S. V., Mittal, P. S., Pahade, A. R. and Rege,S.W.; Development and validation of stability-indicating HPTLC method for estimation of azilsartan medoxomil, Pharma Science Monitor; 6(1), p. 224-232(2015)

6. International Conference on Harmonization ICH Q 2A. text on validation of analytical procedures: methodology (2005)

7. "The Pharmacopoeia of United States of America", $35^{\text {th }}$ Ed., Electronic version.(2012).

8. Ng, L.L.; Reviewer guidance: validation of chromatographic method. FDA center for drug evaluation and research (CDER) (1994)

9. Krull, I.S., Swartz, M.E.; Validation of chromatographic method; Pharm. Tech., 22(3):104-119 (1998).

10. Ng, L.L.; Reviewer guidance: validation of chromatographic method. FDA center for drug evaluation and research (CDER) (1994) 